\title{
PENGARUH PIUTANG DAGANG DAN METODE PENCATATAN HUTANG \\ PIUTANG TERHADAP KETERSEDIAAN MODAL PENJUALAN DALAM PERSPEKTIF EKONOMI ISLAM (STUDI KASUS TOKO BAHAN POKOK DI DESA NUSAMAKMUR KECAMATAN AIR KUMBANG
}

\author{
Muharir \\ Sekolah Tinggi Ekonomi dan Bisnis Syari'ah Indo Global Mandiri \\ ( STEBIS IGM ) Palembang \\ Email : Muharirharir287@gmail.com
}

\begin{abstract}
ABSTRAK
Penelitian ini menganalisis piutang dagang, dan metode pencatatannya dalam perspektif Islam. Penelitian ini bertujuan untuk menganalisis metode pencatatan hutang piutang terhadap ketersediaan modal penjualan dalam perspektif ekonomi Islam studi kasus toko bahan pokok di Desa Nusamakmur Kecamatan Air Kumbang. Metode yang digunakan adalah metode kuantitatif dan metode kualitatif yaitu metode kualitatif merupakan analisis non statistik yang membantu dalam penelitian. Data-data yang diperoleh baik yang berupa angka maupun yang berupa tabel kemudian ditafsirkan dengan baik sesui dengan data yang diperoleh sedangkan metode kuantitatif adalah analisa yang menggunakan bantuan statistik untuk membantu dalam penelitian dalam penghitungan angka-angka untuk menganalisis data yang diperoleh. Berdasarkan hasil penelitian diketahui metode pencatatan terhadap ketersediaan modal usaha penjualan toko bahan pokok Desa Nusamakmur Kecamatan Air Kumbang tidak sesuai dengan perspektif Islam.
\end{abstract}

Kata Kunci : Hutang Piutang Dalam Perspektif Ekonomi Islam

\section{DASAR PEMIKIRAN}

Manusia dituntut bersungguh-sungguh untuk mencari rezeki dan mendapatkan sesuatu yang dicarinya. Ia mendapat manfaat dari orang lain dan sebaliknya memberi manfaat kepada mereka, salah satu diantaranya ialah memberikan piutang tehadap pembeli walaupun pada hakikatnya, seorang pembeli menjadi memiliki hutang, namun hal ini merupakan bentuk kepedulian para pengusaha untuk memberikan piutang, terhadap para pembeli, dengan maksud dan tujuan membantu para pembeli untuk tetap, berbelanja tanpa harus memikirkan pembayaran dengan secara tunai.

Hutang merupakan kewajiban kepada pihak pengusaha yang harus dibayar pada suatu saat tertentu dalam bentuk uang atau jasa (Muslich, 2013: 278). Tidak dapat di pungkiri bahwa pada umumnya pelanggan akan merasa lebih tertarik untuk membeli sebuah produk yang ditawarkan secara kredit oleh sebuah perusahaan ( penjual ) dan ini 


\section{$2 \mid$}

Muharir. Pengaruh Piutang Dagang dan Metode Pencatatan Hutang Piutang...

merupakan salah satu trik untuk meningkatkan omset penjualan yang akan tampak dalam laporan laba ruginya (Hery, 2011: 36).

Dalam hutang piutang juga ada ketentuan didalamnya mengenai keharaman bagi pemberi piutang. Diharamkan bagi pemberi hutang mensyaratkan tambahan dari utang yang ia berikan ketika mengembalikannya. Para ulama sepakat, jika pemberi utang mensyaratkan kepada penghutang pada saat aqad untuk mengembalikan utangnya dengan adanya tambahan, kemudian sipenghutang menerima maka itu adalah riba (Muslich, 2013: 278). Hal ini sesuai dengan kaidah tentang larangan pengambilan manfaat dalam hutang piutang.

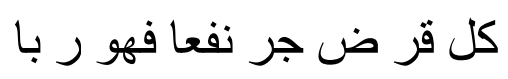

" semua hutang yang menarik manfaat, maka itu termasuk riba" (Sabiq, t.t: 184, al-Khalani, 1960: 54, dan Muslich, 2013: 280)

Perlu diketahui bahwa tambahan yang haram diambil dari pemberian utang adalah tambahan yang disyaratkan seperti seseorang berkata " saya memberimu utang 10.000 dengan syarat engkau mengembalikan dengan tambahan 10.500. maka yang 500, itu tidak di benarkan dalam perspektif Islam.

Didalam akuntansi seringkali disebut piutang dagang, yaitu utang yang timbul akibat pembelian kredit barang atau jasa. Hutang para pembeli yang besar atau kecil tentunya akan mempengaruhi modal usaha seorang pengusaha, ketersedian modal yang besar sangat dibutuhkan bagi seorang pengusaha yang mampu memberikan pinjaman hutang, baik berupa uang maupun barang, kepada para pembeli. Dalam salah satu buku akuntansi dasar 2 akuntansi perusahaan dagang disebutkan “ persediaan barang dagang adalah elemen yang sangat penting dalam penentuan harga pokok penjualan, pada perusahaan dagang eceran maupun perusahaan dagang partai besar (Jusup, 2005: 99).

Persediaan berpengaruh terhadap neraca maupun laporan rugi laba dalam neraca sebuah perusahaan dagang ataupun perusahaan manufaktur, persediaan seringkali merupakan bagian yang sangat besar dari keseluruhan aktiva lancar yang dimiliki oleh perusahaan meskipun demikian, jumlah dan persentasinya berbeda-beda antara perusahaan yang satu dengan yang lainya. Pada usaha tertentu kadang-kadang persediaan menggambarkan $70 \%$ dari keseluruhan aktiva lancar. Angka persentase ini 
merupakan bukti betapa pentingnya kegiatan pembelian dan penjualan persediaan dalam oprasi usaha semacam itu (Jusup, 2005: 100).

Dari uraian penjelasan diatas bahwa persediaan merupakan faktor yang sangat penting dalam masalah penjualan terutama dalam menentukan harga pokok penjualan, pada periode tertentu. Modal yang besar dan persediaan yang maksimal maka akan melancarkan proses jual beli. Bila hal ini dihubungkan dengan piutang yang diberikan oleh pengusaha terlalu tinggi maka akan sangat berpengaruh terhadap ketersediaan modal usaha perdagangan.

Pada sebuah toko yang terletak di Desa Nusamakmur Kecamatan Air Kumbang yang menjual berbagai macam jenis bahan pokok keperluan hidup sehari-hari, di desa ini ada 5 toko yang menjual berbagai macam jenis bahan pokok, di toko ini juga masyarakat berbelanja dalam memenuhi kebutuhan hidup sehari-hari. Masyarakat di desa itu umumnya adalah para petani, pedagang, berkebun,dan ada juga yang merantau keluar daerah, namun yang paling dominan usaha masyarakat adalah berkebun getah karet.

Dalam memenuhi kebutuhan sehari-hari para petani karet berhutang kepada 5 toko di Desa Nusamakmur, setiap bulannya para petani menimbang getahnya atau menjual getahnya kepada para tengkulak, untuk mendapatkan hasil kebunnya, hal ini dilakukan sudah beberapa tahun lamanya, dan para pelaku usaha toko di desa ini khususnya 5 toko di Desa Nusamakmur semuanya adalah para tengkulak getah yang menerima getah para petani karet, setiap bulannya pula para tengkulak atau pengusaha toko ini, menjual barang dagangannya ( bahan pokok ) dengan cara di hutangkan kepada para petani getah, dengan catatan dalam jangka waktu satu bulan maka akan dilakukan pemotongan hutang belanja dari hasil kebun mereka yang mereka jual.

Dalam rangka memenuhi kebutuhan hidup sehari-hari para petani karet juga telah meminjam uang, selain dari mengambil barang-barang kebutuhan pokok kepada para pengusaha toko, namun berdasarkan hasil observasi menunjukkan bahwa pada saat mereka melakukan praktek hutang piutang para pengusaha toko mengambil manfaat dari yang di piutangkan yakni kelebihan dari pembayaran sejumlah uang yang dipiutangkan. Hal ini jelas tidak dibenarkan dalam Islam karena prinsipnya hutang piutang adalah tolong menolong tanpa mengambil manfaat didalamnya. Selain dari pada itu sering kali para penghutang dalam melakukan pembayaran hutangnya, mereka tidak 
sepenuhnya melunasi hutang hutangnya hal ini tentu akan berpengaruh terhadap ketersediaan modal para penjual.

Berdasarkan hasil wawancara ulang kepada para pemilik toko mengatakan “ bahwa pemilik toko harus memiliki modal yang berlebih untuk mengimbangi jumlah total piutang yang belum terbayar pada periode tertentu yang semakin meningkat karna di sebabkan harga penjualan getah karet yang semakin merosot sehingga para petani karet tidak sanggup membayar lunas semua hutang-hutangnya" (Wawancara, Pemilik Toko Bahan Pokok). Bila dilihat dari konsep adharuriyatu khomsah yaitu hifdzul mall maka timbul sebuah kajian dalam perspektif ekonomi Islam seseorang harus menjaga dari pada hartanya untuk bagaimana bertahan hidup dari sisi konsumsi yang cukup, apabila hutang tidak terbayarkan maka para pemilik toko akan terancam hidupnya karna mereka dalam keadaan rugi yang berkepanjangan. Modal yang cukup serta pencatatan yang benar sesui dengan konsep dasar menurut perspektif ekonomi Islam maka permasalahan akan teratasi dengan baik.

Pokok permasalahan adalah terletak pada piutang usaha yang diberikan para pengusaha toko kepada masyarkat di desa itu, seberapa besar pengaruhnya, kemudian apakah para pemilik toko menjalankan praktik hutang piutang sesuai prinsip Islam, bagaimana ketersediaan modal usaha para pengusaha toko di desa Nusamakmur, dan apakah dalam pencatatan hutang piutang sesuai dengan prinsip Islam yaitu pencatatan dengan benar meskipun piutang itu sampai batas waktu yang di sebutkan atau memberikan penangguhan pembayaran dalam jual beli.

\section{METODE PENELITIAN}

Pada metode penelitian ini menggunakan metode penelitian kombinasi kuantitatif dan kualitatif. Metode penelitian kombinasi, merupakan metode penelitian yang berlandaskan pada filsafat pragmatisme menurut Prof. Dr. Sugiyono dari pendapat para ahli beliau menyimpulkan bahwa filsafat pragmatisme itu memandang dunia atau realitas itu tidak merupakan suatu kesatuan yang absolut/ mutlak, tidak hanya menggunakan satu sistem filsafat dalm memandang realitas. Dengan demikian situasi sosial itu bisa bersifat holistik (pospositivisme) tetapi juga dapat diklasifikasikan ( positivisme ) kondisi itu tidak harus natural / alamiah tetapi juga ada perlakuan positivisme. Dengan situasi seperti itu maka peneliti kombinasi dapat melakukan 
penelitian dengan metode kualitatif dan kuantitatif secara bersama-sama (Sugiyono, 2012: 16).

\section{Definisi Operasional}

Variabel penelitian pada dasarnya adalah segala sesuatu yang berbentuk apa saja yang ditetapkan oleh peneliti untuk dipelajari sehingga diperoleh informasi tentang hal tersebut secara teoristis variabel dapat didefinisikan sebagai atribut seseorang, atau obyek yang mempunyai variasi antara satu orang dengan yang lain atau satu obyek dengan obyek yang lain dan variabel biasanya dihubungkan dengan definisi oprasional variabel agar dapat memiliki makna jelas dalam analisanya.

Adapun pengukuran secara oprasional menurut Suharnomo dari masingmasing variabel adalah sebagai Berikut.

\section{Tabel I}

\section{Variabel dan Indikator Penelitian}

\begin{tabular}{|c|c|c|c|c|}
\hline Variabel & Definisi Konsep & $\begin{array}{c}\text { Dimensi (Cara } \\
\text { Ukur) }\end{array}$ & Alat Ukur & Skala \\
\hline $\begin{array}{l}\text { Piutang } \\
\text { Dagang }\end{array}$ & $\begin{array}{l}\text { Piutang dagang adalah } \\
\text { jumlah uang yang harus } \\
\text { dibayar oleh sipembeli } \\
\text { kepada perusahaan }\end{array}$ & $\begin{array}{l}\text { 1. Pencatatan } \\
\text { 2. Penghitungan } \\
\text { 3. Penjelasan }\end{array}$ & $\begin{array}{l}\text { a. Tingkat perputaran piutang } \\
\text { dagang } \\
\text { perputaran piutang } \frac{\text { penjuala }}{\text { rata }- \text { rat }} \\
\text { b. Rata-rata piutang dagang } \\
\text { rata - rata piutang } \frac{\text { p.awal }+ \text { p.ahir }}{2} \\
\text { c. Periode pengumpulan piutang } \\
\frac{\text { rata - rata piutang } X 360}{\text { penjualan kredit }}\end{array}$ & Rasio \\
\hline $\begin{array}{l}\text { Metode } \\
\text { pencatatan }\end{array}$ & $\begin{array}{l}\text { Metode pencatatan } \\
\text { merupakan salah satu } \\
\text { cara dalam menyusun } \\
\text { laporan keuangan sesuai } \\
\text { dengan standar akuntasi }\end{array}$ & $\begin{array}{l}\text { 1. Pencatatan } \\
\text { 2. Penghitungan } \\
\text { 3. Penjelasan }\end{array}$ & Teori pencatatan akuntansi & Analisa \\
\hline $\begin{array}{l}\text { Persediaan } \\
\text { Modal } \\
\text { penjualan }\end{array}$ & $\begin{array}{lr}\text { Persedian } & \text { barang } \\
\text { dagang atau } & \text { modal } \\
\text { usaha penjualan } & \text { dalam } \\
\text { bentuk barang } & \text { adalah } \\
\text { persediaan yang siap } \\
\text { dijual kepada para } \\
\text { konsumen }\end{array}$ & $\begin{array}{l}\text { 1. Pencatatan } \\
\text { 2. Pengitungan } \\
\text { 3. Perolehan } \\
\text { Usaha }\end{array}$ & $\begin{array}{l}\text { perputaran persediaan } \frac{\text { harga pokok penjualan }}{\text { rata }- \text { rata persediaan }} \\
\text { r.persediaan barang } \frac{p \text {.awal }+ \text { p.ahir }}{2} \\
\text { r.persediaantersimpan } \frac{\text { rata }- \text { ratapersediaanX } 3}{\square \text { arga pokok penjualan }}\end{array}$ & Rasio \\
\hline
\end{tabular}


6 | Muharir. Pengaruh Piutang Dagang dan Metode Pencatatan Hutang Piutang...

\begin{tabular}{|l|l|l|l|l|}
\hline $\begin{array}{l}\text { Perspektif } \\
\text { ekonomi }\end{array}$ & $\begin{array}{l}\text { Memberikan suatu yang } \\
\text { menjadi hak milik }\end{array}$ & 1. Pencatatan & & Analisa \\
& $\begin{array}{l}\text { pemberi pinjaman } \\
\text { kepada peminjam }\end{array}$ & 2. Pengitungan & Ayat dan hadits ekonomi & \\
dengan pengembalian & Hukum syar'i & & \\
dikemudian hari sesui & & & \\
& $\begin{array}{l}\text { perjanjian dengan } \\
\text { jumlah yang sama. }\end{array}$ & & & \\
\hline
\end{tabular}

\section{Ruang Lingkup Penelitian}

Ruang lingkup penelitian ini dimaksudkan agar hasil penelitian dan pembahasan ini tidak menyimpang dari permasalahan yang ada maka disini penulis memberikan suatu batasan terhadap pengolahan data dan penyajian data yang di perlukan di Toko Bahan Pokok Desa Nusamakmur Kecamatan Air Kumbang.

\section{Lokasi Penelitian}

Penelitian Dilaksanakan di satu Tempat Yaitu. Toko Bahan Pokok Desa Nusamakmur Kecamatan Air Kumbang.

\section{Sumber Data dan Jenis Data}

Sumber data yang digunakan adalah data primer dan data sekunder.

1. Data Primer

Data primer adalah data yang diperoleh secara langsung dari responden atau objek yang diteliti meliputi karakteristik responden. Dalam penelitian data yang diperoleh di lapangan dan persepsi responden terhadap variabel penelitian.

2. Data Sekunder

Data sekunder adalah data yang diperoleh dari sumber tidak langsung memberikan data kepada pengumpul data (Sugiono, 2006: 128). Data sekunder diperoleh dari data yang ada di Toko Bahan Pokok Desa Nusamakmur Kecamatan Air Kumbang

\section{Jenis Data}

Jenis data yang digunakan dalam penelitian ini adalah kuantitatif dan data kualitatif. Data kualitatif adalah analisa data yang dikelompokan kedalam tabeltabel frekuensi berdasarkan karakteristiknya dan dinyatakan dalam frekuensi absolute dan frekuensi relative (\%) agar mudah dibaca dan dipahami serta untuk mengetahui gejala-gejala data yang terjadi. Sedangkan data kuantitatif adalah analisa data yang dilakukan setelah data penelitian tersebut diolah baik secara 
manual maupun bantuan komputer berarti analisa data kuantitatif berkaitan langsung dengan bilangan atau angka (Sunyoto, 2011: 104).

\section{Populasi dan Sampel}

Dalam penentuan sampel dari populasi pada penelitian ini terbagi menjadi dua yaitu untuk secara random ( acak ) ditujukan kepada pembeli atu penghutang. Berikut pengambilan sampel dengan random acak yang dilakukan kepada para pembeli atau penghutang sebanyak 450 orang penghutang pemilihan sampel nomor urut responden mempunyai selisih 12 dan dimulai dari no urut responden ke-1 yakni no, 12, 23, 35,47, 59, 71, 83, 95, 107,119, 107, 131, 143, 155, 167, 179, 191, 203, $215,227,239,251,263,275,287,299,311,323,335,347,359,371,383,395,407$, $419,431,443$.

Dan secara purposive sampling ditujukan kepada pedagang yakni lima pemilik toko bahan pokok di Desa Nusamakmur Kecamatan Air Kumbang. Sebagaimana telah diketahui bahwapopulasi atau universe adalah jumlah keseluruhan objek (satuan-satuan atau individu-individu ) yang karakteristiknya hendak di duga.satuan-satuan atau individu-individu ini disebut unit analisa (Djarwanto dan Subagyo, 1988: 95). Sedangkan sampel adalah sebagian dari populasi yang karakteristiknya berhak diselidiki dan dianggap bisa mewakili keseluruhan populasi ( jumlah lebih sedikit daripada jumlah populasinya).

Populasi dalam penelitian ini adalah pedagang dan pembeli yang memiliki keterkaitan dengan kegiatan hutang piutang di Toko Bahan Pokok Desa Nusamakmur Kecamatan Air Kumbang yang berjumlah 450 orang peng Hutang dan lima diantaranya adalah pemilik toko. Menurut Hasan Iqbal mengatakan untuk menentukan berapa minimal sampel yang dibutuhkan jika ukuran populasi diketahui, maka dapat digunakan rumus Slovin untuk menentukan jumlah sampelnya seperti berikut :

$n \leq=\frac{\mathrm{N}}{1+\left(\mathrm{Nx} \mathrm{e}^{2}\right)}$

dimana :

$$
\begin{aligned}
& \mathrm{n}=\text { ukuran sampel } \\
& \mathrm{N}=\text { ukuran populasi } \\
& \mathrm{e}=\text { kelonggaran ketidak telitian/presisi karena kesalahan }
\end{aligned}
$$


Pengambilan sampel yang dapat ditoleransi, misal $5 \%$ Jika presisi yang digunakan dalam penelitian ini adalah 5\% ( 0,5 ).( Hasan Iqbal.2002:61 ) maka jumlah sampel yang akan diteliti dari populasi sebesar 450 orang penghutang adalah:

$$
\begin{aligned}
n \leq=\frac{450}{1+\left(450 \times 0,5^{2}\right)} & =\frac{450}{1+(450 \times 0,025)} \\
n & =\frac{450}{1+11,25}=\frac{450}{12,25}=37.73
\end{aligned}
$$

Berdasarkan perhitungan dengan mengacu pada pendapat Slovin dalam penelitian ini diambil sejumlah minimal 38responden( pembulatan ) penelitian, dalam pengambilan sampel diambil secara purposive sampling dan random sempling purposive sampling artinya peneliti mengambil sampel secara sengaja maksudnya peneliti menentukan sendiri sampel yang di ambil. dimana anggota populasi mempunyai kesempatan yang sama untuk dijadikan sampel. Sedangkan random sampling menurut Danang Sunyoto adalah acak sederhana dimana harus memberikan kesempatan seleksi Kepada responden.

\section{Teknik Pengumpulan data}

a. Studi Pustaka

Studi pustaka ini dimaksud untuk mencari penjelasan yang lengkap tentang hutang piutang, metode pencatatan dan persediaan modal penjualan melalaui konsep-konsep teoristis dan penjabaran yang jelas sehingga dapat diperoleh data onformasi yang lebih tepat (Djarwanto dan Subagyo, 1988: 95)

b. Metode Lapangan

Studi lapangan dalam penelitian ini dengan cara penelitian secara langsung pada objek yang diteliti (Djarwanto dan Subagyo, 1988: 165). Dalam studi lapangan ini yang digunakan untuk mengumpulkan data yang diperlukan adalah.

1. Metode Kuesioner

Metode kuesioner adalah metode pengumpulan data dengan cara menggunakan daftar pertanyaan yang dilakukan kepada responden untuk dijawab dengan cara memberikan angket (Djarwanto dan Subagyo, 1988: 170). Pada umumnya isi materi kuesioner meliputi identitas responden dan butirbutir pertanyaan variabel penelitian beserta alternative jawaban kuesiner ini menggunakan sekala likert. 
Tabel.2

\begin{tabular}{|c|c|c|}
\hline No & Jawaban Responden & Skor \\
\hline 1. & Sangat setuju & 5 \\
\hline 2. & Setuju & 4 \\
\hline 3. & Netral & 3 \\
\hline 4. & Tidak setuju & 2 \\
\hline 5. & Sangat tidak setuju & 1 \\
\hline
\end{tabular}

2. Metode Wawancara

Adalah metode pengumpulan data dengan mengajukan pertanyaanpertanyaan secara bebas baik struktur maupun tidak terstruktur dengan tujuan untuk memperoleh informasi secara luas mengenai obyek penelitian (Djarwanto dan Subagyo, 1988: 23)

3. Metode Observasi

Yaitu suatu metode yang digunakan oleh peneliti dengan cara pengamatan langsung terhadap kegiatan yang dilaksanakan perusahaan (Djarwanto dan Subagyo, 1988: 165)

4. Dokumentasi

Metode dokumentasi adalah suatu cara pengumpulan data yang dilakukan dengan cara menganalisis data-data tertulis dalam dokumendokumen berbentuk arsip dan dengan mempelajari catatan-catatan.

\section{Teknik Analisa Data}

a. Analisa Kualitatif

Analisa kualitatif merupakan analisa nonstatistik yang membantu dalam penelitian. Data-data yang diperoleh baik yang berupa angka maupun yang berupa tabel kemudian ditafsirkan dengan baik sesui dengan data yang diperoleh analisa kualitatif digunakan untuk menjelaskan hubungan antara variabel terpengaruh dengan yang mempengaruhi (Sunyoto, 2011: 26). Sebagai hasil data observasi yang telah dilakukan analisa kualitatif adalah sebagi berikut: 
Tabel .3

Jenis Kelamin Responden

\begin{tabular}{|c|c|c|}
\hline Jenis Kelamin & Jumlah & Persentase ( \%) \\
\hline Pria & 11 & $20 \%$ \\
\hline Wanita & 27 & $80 \%$ \\
\hline Jumlah & 38 & $100 \%$ \\
\hline
\end{tabular}

Sumber Data: Data Sekunder yang diolah

Dari tabel 7 diatas dapat diartikan bahwa responden dalam penelitian ini sebagian besar adalah wanita yaitu sebesar 80 persen sedangkan responden pria adalah $20 \%$ hal ini dapat di maklumi karna para pembeli pada umumnya adalah para wanita, dari ke-5 toko bahan pokok yang ada di Desa Nusamakmur Kec. Air Kumbang.

Tabel: 4

Usia Responden

\begin{tabular}{|c|c|c|}
\hline Usia & Jumlah & Persentase (\%) \\
\hline Antara 17 sd 23 tahun & 12 & $26,5 \%$ \\
\hline Antara 24 sd 30 tahun & 20 & $50,5 \%$ \\
\hline Diatas 30 tahun & 8 & $23,3 \%$ \\
\hline Jumlah & & $100 \%$ \\
\hline
\end{tabular}

Suber data :Data sekunder yang diolah

Tabel. 5

Tingkat Pendidikan Responden

Tingkat_pendidikan

\begin{tabular}{|c|c|c|c|c|c|}
\hline & & Frequency & Percent & Valid Percent & $\begin{array}{c}\text { Cumulative } \\
\text { Percent }\end{array}$ \\
\hline \multirow[t]{4}{*}{ Valid } & SD & 14 & $36.8 \%$ & $37.8 \%$ & 37.8 \\
\hline & SMP & 11 & $28.9 \%$ & $29.7 \%$ & 67.6 \\
\hline & SMA & 12 & $31.6 \%$ & $32.4 \%$ & 100.0 \\
\hline & Total & 37 & $97.4 \%$ & $100.0 \%$ & \\
\hline
\end{tabular}


\begin{tabular}{|ll|c|c|c|c|} 
Missing $\quad$ System & 1 & $2.6 \%$ & \\
Total & & 38 & 100.0 & \\
\hline
\end{tabular}

Sumber Data: Data Sekunder yang diolah

Berdasarkan jawaban diatas dapat diketahui bahwa 36,8\% muqridh bependidikan tingkat SD, 28,9\% muqridh berpendidikan tingkat SMP 31,6\% muqridh bependidikan tingkat SMA. Ini menunjukan bahwa mayoritas responden bependidikan tingkat SD.

b. Analisa Kuantitatif

Analisa kuantitatif adalah analisa yang menggunakan bantuan statistik untuk membantu dalam penelitian dalam penghitungan angka-angka.

c. Uji Validitas dan Reliabilitas

Menganalisis data yang diperoleh dengan menggunakan program SPSS karena dengan bantuan penghitungan komputer lebih cepat dan akurat (Sunyoto, 2011: 29).

Uji validitas menunjukkan sejauhmana skor/nilai/ukuran yang diperoleh benar-benar menyatakan hasil pengukuran/pengamatan yang ingin diukur (Sugiono, 2007: 109). Penelitian ini ingin mengetahui data yang valid atau tidak valid dan diuji dengan menggunakan bantuan program SPSS 11.5 dengan taraf signifikasi 5\%.Jika $\mathrm{r}$ hitung positif dan $\mathrm{r}$ hitung $>\mathrm{r}$ table maka, butir tersebut adalah valid. Sedangkan jika $r$ hitung tidak positif serta $r$ hitung $<r$ table maka butir atau variable tersebut tidak valid.Sedangkan uji reabilitas menunjuk pengertian bahwa suatu instrument cukup dapat dipercaya untuk digunakan sebagai alat pengumpul data karena instrument sudah baik (Etta, 2010: 162). Reliabilitas suatu alat pengukur adalah derajat ketetapan dalam mengukur apa saja yang diukurnyaharga kebutuhan pokok naik.

\section{Hasil Uji dan Analisa Data}

\section{a. Uji Validitas dan Reliabilitas}

Validitas berasal dari kata validity yang berarti sejauh mana ketetapan dan kecermatan suatu alat ukur dalam melakukan fungsi ukuranya, uji validasi atau validitas dimaksudkan untuk memastikan seberapa baik suatu instrument konsep yang seharusnya diukur (Syaifudin azwar, 1997:04 ) 
Reliabilitas adalah istilah yang dipakai untuk menunjukan sejauh mana suatu hasil pengukuran relative konsisten apabila pengukuran diulangi dua kali atau lebih ( Azwar,1999) ). Reliabilitas juga dapat berarti indeks yang menunjukan sejauh mana alat pengukur dapat menunjukan dapat dipercaya atau tidak.Uji ini digunakan untuk mengetahui dan mengukur tingkat konsistensi alat kur.

Sebuah instrument penelitian dikatakan valid apabila mampu mengukur apa yang diinginkan dan mampu mengungkap data yang diteliti secara tepat ancok ( dinul Alfian Akbar,2002: 49 ), menyatakan bahwa untuk mengetahui apakah variabel yang diuji valid atau tidak, hasil korelasi dibandingkan dengan angka kritik tabel korelasi dengan tingkat signifikasi $1 \%, 5 \%$ atau $10 \%$ jika angka korelasi perhitungan lebih besar dibandingkan dengan angka kritik maka item pertanyaan tersebut dinyatakan valid dan signifikasi. Begitu pula sebaliknya jika angka korelasi hasil perhitungan lebih kecil dibandingkan dengan angka kritik maka item pertanyaan tersebut dinyatakan tidak valid atau siknifikan.Dan tidak dapat digunakan dalam analisis. Nurul Hikmah ( Dinul Alfian Akbar, 2002: 49 ) menyatakan bahwa jika $\mathrm{r}$ hasil ( Corrected item totalncorrelation ( CI-TC ) pada output SPSS) bernilai positif serta $\mathrm{r}$ hasil $>\mathrm{r}$ tabel maka butir atau variabel tersebut valid.

Uji reliabilitas instrument dapat dilihat besarnya nilai Cronbach Alpha pada masing-masing variabel. Cronbach alpha digunakan untuk mengetahui reliabilitas konsisten inter item, atau untuk menguji konsistenan responden dalam merespon dalam merespon seluruh item.

Berdasarkan hasil perhitungan dengan menggunakan program SPSS dengan tingkat signifikasi $10 \%$ atau 0,1 besaranya nilai $r$ tabel untuk $n=179$ ini berarti nilai lebih dekat dengan anggka 200 maka dapat di lihat pada $r$ tabel pada posisi angka 0,181 sebelum mendapatkan hasil uji validasi dan reliabilitas, langkah yang diambil dalam penjumlahan pembuatan tabulasi dari skor jawaban masing-masing responden dapat dilihat dari tabel hasil jawaban kuesioner Tingkat upah ( variabel X ) dan Kinerja buruh ( variabel Y ) sebagai berikut: 


\section{b. Uji Validitas}

Tabel: 6

Uji Validitas Butir (Independent)

\begin{tabular}{|l|l|l|l|l|}
\hline Variabel & Item & CI-TC & r tabel & Status \\
\hline \multirow{4}{*}{ Variabel Tingkat } & $\mathrm{X} 1$ & 0.285 & 0,181 & Valid \\
\cline { 2 - 5 } & $\mathrm{X} 2$ & 0.405 & 0,181 & Valid \\
\cline { 2 - 5 } & $\mathrm{X} 3$ & 0.573 & 0,181 & Valid \\
\cline { 2 - 5 } & $\mathrm{X} 4$ & 0.677 & 0,181 & Valid \\
\cline { 2 - 5 } & $\mathrm{X} 5$ & 0.483 & 0,181 & Valid \\
\hline $\mathrm{X} 6$ & 0.469 & 0,181 & Valid \\
\cline { 2 - 5 } & $\mathrm{X} 7$ & 0.601 & 0,181 & Valid \\
\cline { 2 - 5 } & $\mathrm{X} 8$ & 0.699 & 0,181 & Valid \\
\cline { 2 - 5 } & $\mathrm{X} 9$ & 0.662 & 0,181 & Valid \\
\cline { 2 - 5 } & $\mathrm{X} 10$ & 0.535 & 0,181 & Valid \\
\hline
\end{tabular}

Sumber: Data Primer yang diolah, 2019

Keterangan: CI-TC: Corrected Item-Total Correlation

Tabel : 7

Uji Validitas Butir (Dependent)

\begin{tabular}{|l|l|l|l|l|}
\hline Variabel & Item & CI-TC & r tabel & Status \\
\hline Variabel Kinerja Buruh & $\mathrm{Y} 1$ & 0.518 & 0,181 & Valid \\
\cline { 2 - 5 } & $\mathrm{Y} 2$ & 0.601 & 0,181 & Valid \\
\cline { 2 - 5 } & $\mathrm{Y} 3$ & 0.580 & 0,181 & Valid \\
\cline { 2 - 5 } & $\mathrm{Y} 4$ & 0.614 & 0,181 & Valid \\
\cline { 2 - 5 } & Y5 & 0.707 & 0,181 & Valid \\
\cline { 2 - 5 } & Y6 & 0.663 & 0,181 & Valid \\
\cline { 2 - 5 } & Y7 & 0.595 & 0,181 & Valid \\
\cline { 2 - 5 } & Y8 & 0.549 & 0,181 & Valid \\
\cline { 2 - 5 } & Y9 & 0.619 & 0,181 & Valid \\
\cline { 2 - 5 } & Y10 & 0.637 & 0,181 & Valid \\
\hline
\end{tabular}

Sumber: Data Primer yang diolah, 2019

Keterangan :CI-TC: Corrected Item-Total Correlation 
Berdasarkan tabel diatas dapat diketahui bahwa kuesioner yang digunakan untuk mengukur variabel-variabel tingkat upah sebagai variabel $\mathrm{X}$ dan kinerja buruh sebagai variabel Y, dapat dinyatakan valid. Validitas kuesioner ditunjukkan dengan koefisien korelasi ( $\mathrm{r}$ hitung atau CI-TC) lebih besar dari $\mathrm{r}$ hitung untuk $\mathrm{n}=179$ yaitu 0,181 dengan tingkat signifikan $10 \%$.

\section{c. Uji Reliabilitas}

Reliabilitas adalah tingkat ketepatan, ketelitian atau keakuratan sebuah instrument, jadi reliabilitas menunjukkan apakah instrument tersebut secara konsisten memberikan hasil ukuran yang sama tentang sesuatu yang diukur pada waktu yang berlainan (Siswoyo,2004:195). Uji reliabilitas atau uji konsistensi suatu item pertanyaan dengan membandingkan antara nilai cronbach's alpha dan taraf keyakinan (coefficients of confidance $=\mathrm{CC}$ ) dengan ketentuan sebagai berikut:

a. Jika CC < cronbach's alpha, item pertanyaan reliabel (konsisten)

b. Jika CC > cronbach's alpha, item pertanyaan tidak reliabel (tidak konsisten)

Suatu variabel dapat dikatakan reliable jika memberikan nilai cronbach alpha > 0,60. Hasilperhitungan dapat dilihat pada tabel berikut ini:

Tabel :8

Hasil Uji Reliabilitas

\begin{tabular}{|l|l|l|}
\hline Variabel & Cronbach's Alpha & Status \\
\hline VAriabel Tingkat Upah & 0.733 & \\
\hline Variabel Kinerja Buruh & 0.738 & Reliabel \\
\hline
\end{tabular}

Sumber: Data Primer diolah,2019

Berdasarkan tabel reliabilitas di atas, maka konsistensi alat ukur berada diposisi 0,60 dapat diterima. Dengan Cronbach's Alpha untuk variabel Tingkat Upah (X) sebesar 0,733 dan variabel Kinerja Buruh (Y) sebesar 0,738. Dengan demikian seluruh item pertanyaan pada kuesioner penelitian ini dapat dinyatakan reliable.

\section{d. Analisis Regresi}

Digunakan untuk mengetahui hubungan antara variabel X (Tingkat upah) dan variabel Y (Kinerja buruh), maka digunakan model umum persamaan regresi linier, yakni : 
Persamaan regresi

$$
\mathrm{Y}=\mathrm{a}+\mathrm{bX}
$$

Keterangan :

$\mathrm{Y}=$ Produktivitas kerja karyawan

$\mathrm{b}=$ slope atau Koefisien regresi

$\mathrm{a}=$ intersep

Nilai t tabel yang digunakan untuk mengetahui hubungan antara tingkat upah dan kinerja buruh pada Perkebunan Kelapa Sawit PT. Tunas Baru Lampung Kec.Banyuasin I Kab.Banyuasin yaitu sebesar.

\section{Coefficients $^{\mathrm{a}}$}

\begin{tabular}{|c|c|c|c|c|c|c|}
\hline & \multirow{2}{*}{ Model } & \multicolumn{2}{|c|}{ Unstandardized Coefficients } & \multirow{2}{*}{$\begin{array}{c}\begin{array}{c}\text { Standardized } \\
\text { Coefficients }\end{array} \\
\text { Beta }\end{array}$} & \multirow{2}{*}{$\mathrm{t}$} & \multirow{2}{*}{ Sig. } \\
\hline & & B & Std. Error & & & \\
\hline \multirow[t]{2}{*}{1} & (Constant) & 33.043 & 2.332 & & 14.167 & .000 \\
\hline & UPAH & .235 & .056 & .299 & 4.168 & .000 \\
\hline
\end{tabular}

a. Dependent Variable: KINERJA

\section{Coefficients}

Persamaan regresi

$$
\begin{aligned}
\mathrm{Y} & =\mathbf{a}+\mathbf{b x} \\
& =\mathbf{3 3}, \mathbf{6 5 8}+\mathbf{0 , 2 3 5} \mathrm{X}
\end{aligned}
$$

Keterangan :

a. Konstanta sebesar 33,658 menyatakan bahwa jika tidak ada Tingkat upah maka kinerja buruh akan tetap berada pada posisi 33,658

b. Koifisien tingkat upah sebesar 0,235 menyatakan bahwa penambahan tingkat upah akan meningkatkan kinerja buruh sebesar 0,235

Item tingkat upah ( Variabel X ) x1 x2 x3 x4 x5 x6 x7 x8 x9 x10 secara keseluruhan berpengaruh secara signifikan terhadap kinerja buruh (Variabel Y) y1 y2 y3 y4 y5 y6 y7 y8 y9 y10 pada Perkebunan Kelapa Sawit PT. tunas Baru Lampung Kec.BanyuasinI Kab. Banyuasin. Hal ini dibuktikan dengan nilai t hitung sebesar 4,168 yang melebihi nilai t tabel sebesar ( 1,653) dan angka 
16 | Muharir. Pengaruh Piutang Dagang dan Metode Pencatatan Hutang Piutang...

signifikan ( $\mathrm{p}$ ) di bawah 0,05 yakni 0,000 maka dengan demikian “ hipotesis 1 di dukung “

- Keterangan dengan melihat $t$ hitung :

Jia t hitung > t tabel maka H0 ditolak, artinya ada pengaruh antara tingkat upah yang diberikan terhadap kinerja buruh pada perkebunan Kelapa Sawit PT. Tunas Baru Lampung Kec. Banyuasin I kab. Banyuasin.

Jika t hitung $<\mathrm{t}$ tabel maka H0 diterima, artinya tidak ada pengaruh antara tingkat upah dan kinerja buruh pada Perkebunan Kelapa Sawit PT. Tunas Baru lampung Kec. Banyuasin I Kab. Banyuasin.

Model Summary.

Tabel : 9

Hasil Analisis Regresi Model Summary

Model Summary

\begin{tabular}{|c|c|c|c|c|}
\hline Model & $\mathrm{R}$ & $\mathrm{R}$ Square & Adjusted R Square & $\begin{array}{c}\text { Std. Error of the } \\
\text { Estimate }\end{array}$ \\
\hline 1 & $.299^{\mathrm{a}}$ & .089 & .084 & 4.047 \\
\hline
\end{tabular}

a. Predictors: (Constant), UPAH

Keterangan :

- Angka R sebesar 0, 299 menunjukan bahwa regresi tingkat upah terhadap kinerja buruh adalah rendah.

- Angka R squaere sebesar .089 hal ini berarti 8,9\% variasi dari tingkat upah dapat dijelasakan oleh variabel kinerja, sedangkan sisanya $(100 \%-8,9 \%=$ $91,1 \%$ ) dijelaskan oleh faktor-faktor lain.

e. Hubungan Tingkat Upah terhadap Kinerja Buruh Pada Perkebunan Kelapa Sawit PT. Tunas Baru Lampung Kec.Banyuasinm I Kab.Banyuasin.

\section{Korelasi}

Model korelasi digunakan utuk menguji apakah terdapat hubungan antara tingkat upah terhadap kinerja buruh pada Perkebunan Kelapa Sawit PT. Tunas Baru Lampung Kec.Banyuasinm I Kab.Banyuasin.dan untuk 
mengetahui bagaimana hubungan yang terjadi antara tingkat upah ( Variabel X ) terhadap kinerja buruh ( Variabel Y ) .

Hasil analisis korelasi dapat ditunjukan pada tabel IV. 31

$$
r=\frac{n\left(\sum X Y\right)-\left(\sum X\right)\left(\sum Y\right)}{\sqrt{n\left(\sum X^{2}\left(\sum X\right)^{2}\right]^{\circ}\left[n\left(\sum Y\right)^{2}\right]}}
$$

Keterangan:

$$
\begin{aligned}
& \mathrm{r}=\text { nilai koefesien korelasi } \\
& \mathrm{n}=\text { jumlah data } \\
& \mathrm{X}=\text { Tingkat upah } \\
& \mathrm{Y}=\text { Kinerja buruh }
\end{aligned}
$$

\section{Correlations}

Tabel : 10

\section{Hasil Analisis Korelasi}

\section{Correlations}

\begin{tabular}{|ll|l|l|}
\hline & & UPAH & KINERJA \\
\hline UPAH & Pearson Correlation & 1 & $.299^{* *}$ \\
& Sig. (2-tailed) & & .000 \\
& $\mathrm{~N}$ & 179 & 179 \\
\hline KINERJA & Pearson Correlation & $.299^{* *}$ & 1 \\
& Sig. (2-tailed) & .000 & \\
& $\mathrm{~N}$ & 179 & 179 \\
\hline
\end{tabular}

**. Correlation is significant at the 0.01 level (2-tailed).

Keterangan dengan melihat signifikan :

Jika probabilitas $(p)>0,05$ maka H0 diterima artinya tidak ada hubungan

Jika probabilitas $(p)<0,05$ maka $\mathrm{H} 0$ di tolak artinya ada hubungan.

Berdasarkan Tabel IV. 31 diatas dapat di ketahui bahwa: hasil analisis korelasi antara item tingkat upah ( Variabel X ), x1, x2, x3, x4, x5, x6, x7, x8, x10, secara keseluruhan terhadap kinerja buruh ( Variabel Y ), y1, y2, y3, y4,y5, y6, y7, y8, y9, 
18 | Muharir. Pengaruh Piutang Dagang dan Metode Pencatatan Hutang Piutang...

y10, menunjukan bahwa variabel X mempunyai hubungan yang positif ( searah ) dan signifikan terhadap kinerja buruh, yaitu korelasi $(r)=0,299$ dan probabilitas $(p)$ sigifikan pada $\mathrm{p}<0,05$.

Jadi berdasarkan analisis korelasi diatas, dapat disimpulkan bahwa terdapat hubungan positif ( searah ) dan signifikan antara tingkat upah terhadap kinerja buruh pada Perkebunan Kelapa Sawit PT. Tunas Baru Lampung Kec.Banyuasin I Kab.Banyuasin. hubungan posif ( searah ) menunjukan bahwa semakin besar tingkat upah, maka kinerja buruh cenderung semakin meningkat. Berdasarkan hasil tersebut maka “ hipotesis 2 di dukung “

\section{DAFTAR PUSTAKA}

Abdul Kodir Koko. Metodologi Setudi Islam. Bandung: Pustaka Setia. 2002

Al Haryono. Dasar-Dasar Akuntansi. Yogyakarta: STIE YKPN. 2005

Al-Qur'anul Karim

Aravik, Havis, 2016. Ekonomi Islam; Teori, Konsep dan Aplikasi Serta Pandangan Pemikir Ekonomi Islam dari Abu Ubaid Sampai Al-Maududi, Malang: Empat Dua.

Az-Zuhaili Wahbah, Tafsir Al-Wasith ( Alfatihah-At-Taubah) Jilid 1 Jakarta ; Gema Insani, 2012

Baridwan, Manajemen Akuntansi, Jakarta ; Kenta Muda , 2004

Danang Sunyoto, Metodologi Penelitian Ekonomi, Yogyakarta: CAPS. 2011

Evaluasi Terhadap Sistem Pencatatan Akuntansi Pada Usaha Mikro,. Kecil Dan Menengah (Studi Kasus Di Kota Semarang), Semarang: Universitas Diponegoro. 2014

Firdaus Muhammad. Ekonometrika Suatu Pendekatan Aplikatif. Jakarta: Sinar Grafika Offset PT.Bumi Aksara. 2011

Gade Muhammad Dkk, Akuntansi Keuangan Menengah 1, Jakarta: Fakultas Ekonomi Universitas Indonesia. 2005.

Ghazali Al-, Menjawab 100 Soal Keislaman, Tanggerang: Lentera Hati. 2012

Haryono Jusup Dasar-Dasar Akuntansi, Yogyakarta: PT. Kentamuda Karya Bangsa. , 2005.

Herliana DKK, Analisis Pengaruh Perputaran Persediaan Bahan Baku Terhadap Laba Perusahaan Pada PT. Almi Caterindopalembang, Palembang; Politeknik PalComTech Palembang. 2008

Hery. Akuntansi Aktiva,Utang dan Modal. Yogyakarta : Gava media. 2011 
http//. www.blogspot.com. Alwi Musa Muzayyin. Utang Piutang Dalam Ekonomi Islam. 2012 .

http//.www.S.T.I.A.D.I.com/ Pengaruh upah dan jaminan social terhadap produktivitas kerja di PT.Semarang Makmur Semarang.

http://ekonomi.kompasiana.com/moneter/2013/04/28/pengertian-modal-555644.html http://www.artikata.com/arti -322757-buruh.html

Isma'il Ibn Kathir Abu al-Fida, Tafsir Ibnu Katsir, Bogor ; Pustaka Imam Syafi'i. 2004

Jalaluddin Al-Mahalli. Jalaluddin As-Suyuti. Tafsir Jalalain. Jakarta: Bumi Aksara. 2011

Jusup Hartono. Dasar-Dasar Akuntan. Yogyakarta: Kenta Muda Karya Bangsa.2005

Kasmir, ,2014, Analisis Laporan Keuangan, Jakarta; PT. Raja Grafindo persada

Martono, Bank dan Lembaga Keuangan Lainnya, Jakarta: PT. Rineka Cipta. 2002

Mega Mulianti Fitri. Analisis Faktor-Faktor yangMempengaruhi Kebijakan Hutang danPengaruhnya Terhadap NilaiPerusahaan(Studi Pada Perusahaan Manufaktur yang Terdaftar di BursaEfek Indonesia (BEI) Periode Tahun 20042007) Universitas Diponegoro. 2010

Muhammad Isma'il Al-Bukhari Ibnu Abdullah, Al-kitab Sarah Bukhori, Indonesia, Jus 2 ,

Nasib Ar-rifa'i Muhammad, Kemudahan Dari Allah Ringkasan Tafsir Ibnu Katsir Jilid 1 ,Jakarta; Gema Insani, 1999

Ps Djarwanto, Subagyo P. Metodologi Dalam Pengembanganya. jakarta : Citra Kencana. 1988

Pusat Pengkajian Hukum Islam dan Masyarakat Madani PPHIMM. Komplikasi Hukum Ekonomi Syari'ah. Jakarta; Kencana Prenada Media Grup. 2008

Qardhawi Yusuf. Halal Haram Dalam Islam. Solo: Era inter Medi. 2008

Riyanto Bambang, Dasar-dasar Pembelanjaan Perusahaan, Yogyakarta; BPFE Universitas Gajah Mada. 2001

Sangadji Mamang Etta. Metodologi Penelitian Pendekatan Praktis Dalam Penelitia. Yogyakarta: CV Andi Offset. 2010

Simangusong.Pelajaran Akuntansi Dasar Dua. Jakarta : Karya Utama. 1993

Sugiono, Metodologi Penelitian Dalam Islam. jakarta: Citra Kencana. 2007

Sugiono. Metodologi Penelitian Dalam Islam, Jakarta: Citra Kencana. 2006

Sugiyono, Metode Penelitian Kuantitatif, Kualitatif, dan Kombinasi ( Mixed Methods )

( Bandung; Alfabeta, 2012

Sunyoto Danang, Metodologi Penelitian Ekonomi. Yogyakarta: CAPS. 2011

Supriyono Maryanto, Buku Pintar Perbankan, Yogyakarta; C.V Andi Offset, 2011 
Sutrisno, Manajemen Keuangan Teori, Konsep dan Aplikasi, Yogyakarta; Ekonisia. 2009 ,

Sutrisno, Manajemen Keuangan Teori, Konsep dan Aplikasi. Cetakan VII. Yogyakarta: Ekonisia. 2009

Syafe'i Rachmat, Ilmu Ushul Fiqih, Bandung; Pustaka Setia, 2010

Syamsuddin Lukman, Manajemen Keuangan Perusahaan, Jakarta; PT. Raja Grafindo Persada. 2000

Syamsuddin Lukman. Manajemen Keuangan Perusahaan, Jakarta: PT. Raja Grafindo Persada. 2000

Wardi Muslich Ahmad. Fiqih Muamalat. Jakarta: Amzah.2013

Wikipedia, Regresi Linier, 3 mei 2014. 